\title{
The Changes in Language and Dressing of Females on Impact of Indian Dramas
}

\section{Sumiya Wahid*}

Department of Sociology, University of Management and Technology, Lahore, Punjab, Pakistan

\begin{abstract}
The arrival of any new technologies always leave an impact on society, it may be positive or negative depending upon its user. The study indicates that the "impact of Indian dramas on language and dressing of female students studying in Kinnaird College for Women" through analysis and bar charts of previous researches done on this topic were selected as a tool to gather information. Mothers are the main origin of education and learning for their children. Change in their viewpoint, conduct and language leads to change the society culture, values and customs. In this way data was collected from one hundred women who belong to 16 to 30 years' age group and have access to cable network. The present study documented the time spending, watching habits, favorite channels. The study tells us that Indian dramas are very much popular among the respondents and the respondents are constantly being influenced by them which can be proved by the use of Hindi words in their everyday life and their dressing sense. The study further opened our eyes to the fact that Indian culture and norms have penetrated our society and the reason for this is the popularity of these Indian dramas.
\end{abstract}

Keywords: Indian dramas; Language; Dressing; Cultivation

\section{Introduction}

Due to the critical role of media in Pakistan and its unrestricted and cheap access to every house has made it very dangerous. Various international and national channels are available to be watched by the audience. However, the Drama industry of India is losing its firm grip on the market due to steady progression of Pakistani Dramas with strong themes. However, it must be kept in mind that Indian dramas still have a firm grip on the industry that will take a long time to completely lose its value. Indian culture has crept up into Pakistani culture which can be seen by the heavy use of jewelry in most Pakistani households. We are moving away from our cultural values and embracing western culture.

\section{Statement of Problem}

The dressing of females has been influenced by Indian dramas. The females have been treating their family the same way they see on Indian dramas. Indian dramas have become a source of exploitation in the dressing of female. Language is being challenged due to the Adverse Effects of Indian dramas.

\section{The influence of Indian culture on Pakistani society}

Pakistan is a Muslim country which operates under Sharia Law. We have our own Islamic cultural values and it shows us how to spend our lives in accordance with our religion. The Indian channels that are seen by Pakistani viewers have led to us adopting their culture into our own. Now we use their customs in our traditions.

This can be seen by the way we now celebrate our own festivals. Many of the traditions we observe during marriage and the dowry culture in Pakistan are the direct products of this phenomena. Even the Basant festival is originally an Indian festival. Many of the young Pakistanis use Indian tunes for their mobile. Many Hindi words are now used normally by Pakistani citizens.

\section{Impact of Indian dramas on Urdu language}

Urdu is Pakistan's national language and also a very rich one. Urdu is pure and precious; we must not add any other language into it.
These Indian dramas have resulted in Hindi words like 'abay', 'raksha', 'bandhan' etc. to our Urdu language and this has become very common. The children have no idea what the correct and proper Urdu is.

Instead of promoting their story, these dramas do their best to promote the Hindi culture as can be seen by the extensive scenes featuring their festivals like Holi, Raksha Bandhan, Karva-Chauth etc. And this has led to events like Holi and Valentines being organized in Pakistan. They attempt to make the audience follow them blindly. These shows are broadcasted without any set censorship policy. It is obvious that we are losing appreciation of our mother tongue due to the highly predisposed by the linguistic used in the Indian dramas.

\section{Behavior of children with their parents}

Islam has always taught everyone to respect parents the most and to be obedient of them. However now, the children do not follow this practice. They wish to have all of their demands met and if not, they fight with their parents, quarrel, shout at them and misbehave. The Islamic teachings of interaction with $\mathrm{Na}$-Mehrams are not followed anymore. The youngsters go for co-education and relationships have become so common even between early teens. The media has made love marriage fascinating and suicides and murders are reported regularly when the parents do not agree with their children regarding this.

\section{Indian dramas effect on our education}

The youngsters have totally disregarded education and are more attracted to lifestyle of their favorite showbiz personalities but have no knowledge life of our dear Holy Prophet (P.B.U.H). They are

*Corresponding author: Sumiya Wahid, Department of Sociology, University of Management and Technology, Lahore, Punjab, Pakistan, Tel: +92 42111300200 E-mail: sumiyawahid@yahoo.com

Received January 30, 2018; Accepted July 24, 2018; Published July 30, 2018

Citation: Wahid S (2018) The Changes in Language and Dressing of Females on Impact of Indian Dramas. J Mass Communicat Journalism 8: 380. doi: 10.4172/2165-7912.1000380

Copyright: (c) 2018 Wahid S. This is an open-access article distributed under the terms of the Creative Commons Attribution License, which permits unrestricted use, distribution, and reproduction in any medium, provided the original author and source are credited. 
completely conscious of days like Valentines or April's Fool but have no knowledge of our historic days like Defense Day. Illegal means have become commonplace, like cheating.

\section{Objectives}

Objectives were set to precede the current study:

1. To investigate how watching Indian serials influence viewers.

2. To check how much factors of Indian dramas have been adopted by our society.

3. To check to what extent has Hindi been incorporated in our language.

\section{Literature Review}

The actual focus of the research would be to assess the results associated with upon women's life arrays according associated with language as well as outfitting design within Kinnaird College. Joshi [1] offers surveyed the actual involvement associated with ladies within choice producing from Indian TV (Door Darshan). The study associated with ladies' audiences within Madras town signifies the actual superficiality associated with women's applications. 'But my personal research targets the actual effect associated with Indian native dramas upon women concerning the outfitting as well as vocabulary.

As Rahim [2] pointed out the actual alter within the way of life associated with ladies within Hyderabad. He reviews the actual modifications within the conduct associated with standard average women in lots of ways. The actual conversation along with loved ones rejoiced. Period invest within socialism additionally reduced. Cooking food design transformed, leading to the actual intro associated with brand new meals. Gown, perspective as well as look had been disrupted together with vocabulary.

Zia [3] mentioned how the causes of this particular quick development associated with cable TV to incorporate comfortable access, inexpensive, use of satellite television stations along with a large TV viewer-ship thinking about amusement just. Individuals love Indian native movies, dramas as well as advertisements plus they discover several things in the international press. Pakistani lifestyle may be the distinctive design associated with perception, suggestions, ideals extremely affected through the faith associated with Islam.

Islam within Pakistan models the actual signal associated with integrity within the social existence for those individuals associated with Pakistan. However individuals acquired traditional western as well as Indian native lifestyle because of acculturations modernization as well as westernization. Pakistan comes with an effect associated with Indian native outfitting lifestyle too. Right now, individuals prefer to put on Sarhi, Patiala Shalwar, sleeveless gown, brief $t$ shirts as well as much less utilization of dupatta etc. [4]

Within Pakistan, the drama industry created an abrupt effect on thoughts associated with individuals. The Pakistani drama stations tend to be extremely affected through Indian drama as well as traditional western stations as well as attempting to contend with these types of stations in order to function since the translator for the culture. They're losing its social identification through revealing, glamour, love, and so on. The actual Indian dramas and films possess regular as well as rigorous damaging effect on the interpersonal, social, spiritual values as well as ideals associated with Pakistani youngsters. All of us tend to be taking this.
Media is actually actively playing an essential part within the marketing associated with Hindi vocabulary within Pakistan. Simply because individuals, mainly view Indian native applications plus they follow numerous Hindi phrases. These people make use of Hindi phrases within every day regimen like; didi (sibling) "shanty" (sakoon) "vishwas" (trust) "pati" (spouse). Indian native TV shows possess led seriously towards the Sankritisation of Urdu within our country and this has already documented that lots of Hindi phrases for example Chinta, Namaste that have been a good natural a part of Sanskritized Hindi, possess joined regular utilization within Pakistan because of the impact of those Bollywood films as well as Indian native dramas. Press exhibits modernization as well as westernization and contains an adverse effect on the initial lifestyle, talented through Islam; however, we're not really denying the actual Indian native type of outfitting that people possess modified is actually poor. The actual good examples tend to be putting on away Sarhi, Sleeveless, brief $t$ shirts, much less utilization of cheddars, and so on. Upon unique events females make use of in order to put on Indian native lifestyle to exhibit away. This stuff tends to be discovered via Indian native dramas as well as films.

\section{Cultivation Theory}

The Cultivation Theory claims that large audiences associated with Indian native dramas' behavior tend to be reliant mainly through which funnel these people view upon TV. Gerbner sights this particular TV world because "not the eye-port upon or perhaps a representation from the globe, however a global within itself" [5]. Farming Concept, within fundamental shows that TV accounts for framing audiences concepts associated with interpersonal actuality. The actual mixed impact associated with substantial TV publicity through audiences with time quietly designs the actual belief associated with interpersonal actuality for people as well as, eventually, for the lifestyle in general. Therefore, farming investigation is within the results custom. Cultivation theorists argue that TV offers long-term results that are little, steady, roundabout however cumulative as well as substantial. Nevertheless, the actual Gerbner's function provides the Interpersonal Mindset Concept upon conversation impact on marketing because associated media. He or she argues how the media develop behavior as well as ideals that are currently contained in the actual lifestyle. Press keeps as well as advances these types of ideals among people of the lifestyle, therefore joining this collectively. The actual Farming Concept obtained it's begin with the actual farming theory, developed by George Gerbner, that efforts to comprehend exactly how "heavy contact with social symbolism may form the audience's idea of reality" [6].

\section{Research Methodology}

This research is qualitative in nature. The following chapter will delineate research methods used to obtain data in this regard. Figurative analysis and bar charts of previous researches done on this topic were selected as a tool to gather information so, that the main phenomenon of the research can be examined closely and critically, while remaining focused on one unit.

\section{Population}

The population for the research was the females who belong to 16 to 30 years age group and have access to cable network specifically Indian dramas.

\section{Sampling}

The Convenient and Purposive sampling techniques were used in this research. Figurative analysis and bar charts were taken as sample. 
Citation: Wahid S (2018) The Changes in Language and Dressing of Females on Impact of Indian Dramas. J Mass Communicat Journalism 8: 380. doi: $10.4172 / 2165-7912.1000380$

Page 3 of 5

The component of study of the current study is the females of diverse age groups. Data is primarily collected by females of Kinnaird College who belong to 16 to 30 years age group.

\section{Analysis}

In this chapter we will discuss results that are obtained through figurative analysis of previous researches done on this topic. Bar graphs will also be used to indicate the results and also for simple and clear understanding.

\section{Illustration of data}

Table 1 reveals to that half of the respondents watch Star Plus Besides the middle of them $19 \%$ have a place with $16-20$ period groups, $17 \%$ have a place with $21-24$ period bunches. Also $14 \%$ have a place with 25-30 period Assemblies. 34\% of the respondents watch Zee television the middle of them $16 \%$ have a place with $16-20$ age groups, $15 \%$ have a place with $21-24$ age class and $3 \%$ have a place with $25-30$ period gatherings.

Table 2 reveals to that half of the respondents determinedly consented that Indian dramatizations need aid the best hotspot of majority of the data once new configuration What's more mold patterns the middle of them $22 \%$ have a place with $16-20$ age, $20 \%$ have a place with $21-24$ age class and $8 \%$ have a place with $25-30$ period aggregations. $21 \%$ of the respondents disagreed that Indian dramatizations need aid those best sourball from claiming data around new configuration.

As stated by crosstabs, comes about from claiming table shown that those $23 \%$ respondents viewed one day a week, $18 \%$ viewed two times to particular case week, those viewers $(13 \%)$ three times a week,
$19 \%$ for four days a week, $16 \%$ five times a week, $3 \%$ six days a week, Furthermore $7 \%$ watch Indian prime occasion dramas 07 days a week. Those denoted Contrast the middle of the viewership utilization examples of Indian prime duration of the time dramatizations is clear. The recurrence to viewing Indian prime the long run dramatizations were separated under two classifications. The of viewership from one day to three days was underwhelming while viewership from four days to seven times a week showed overwhelming viewership of the Indian prime run through dramatizations. This division originated fascinating realities about the education level of the respondents.

\section{Discussion}

The general results discovered that majority respondent preferred to watch star plus and their favorite watching time are after $7 \mathrm{pm}$. According to the results majority of respondent themselves have control over the remote. So we should create awareness among people about the importance of language and about the bad impacts of other language on our identification. Pakistan is a Muslim state and Pakistani culture is the distinctive model of beliefs, ideas and values highly affected by Islam. Islam in Pakistan sets code of morality for the cultural life for the people of people of Pakistan. But people acquired Indian culture and western due to assimilate, deviation and westernization. Indian dressing culture has a vast impact on the females studying in Kinnaird College. Presently, individuals get a kick out of the chance to have on Sarhi, sleeveless shirts, pants top, short shirts and they don't utilize dupatta or cloak on them. On uncommon minute, females use to wear Indian dressing to show themselves off. This can be seen amid the elements of present day urban communities of Pakistan. Individuals have intelligent these things from Indian dramatization and films at most. Star Plus is the most renowned station between all the satellite TV stations.

\begin{tabular}{|c|c|c|c|c|c|c|}
\hline & & & & Age & & Total \\
\hline & & & $16-20$ & $21-24$ & $25-30$ & \\
\hline \multirow{8}{*}{$\begin{array}{c}\text { Which cable television } \\
\text { channel do you } \\
\text { generally watch? }\end{array}$} & Star plus & Count & 19 & 17 & 14 & 50 \\
\hline & & $\%$ of Total & $19.0 \%$ & $17.0 \%$ & $14.0 \%$ & $50.0 \%$ \\
\hline & \multirow[t]{2}{*}{ Colors } & Count & 6 & 5 & 0 & 11 \\
\hline & & $\%$ of Total & $6.0 \%$ & $5.0 \%$ & $0 \%$ & $11.0 \%$ \\
\hline & \multirow[t]{2}{*}{ zee TV } & Count & 16 & 15 & 3 & 34 \\
\hline & & $\%$ of Total & $16.0 \%$ & $15.0 \%$ & $3.0 \%$ & $34.0 \%$ \\
\hline & \multirow[t]{2}{*}{ Life ok } & Count & 4 & 1 & 0 & 5 \\
\hline & & $\%$ of Total & $4.0 \%$ & $1.0 \%$ & $0 \%$ & $5.0 \%$ \\
\hline \multirow[t]{2}{*}{ Total } & & Count & 45 & 38 & 17 & 100 \\
\hline & & $\%$ of Total & $45.0 \%$ & $38.0 \%$ & $17.0 \%$ & $100.0 \%$ \\
\hline
\end{tabular}

Table 1: Illustration of data.

\begin{tabular}{|c|c|c|c|c|c|c|}
\hline & & & & Age & & Total \\
\hline & & & $16-20$ & $21-24$ & $25-30$ & \\
\hline \multirow{8}{*}{$\begin{array}{l}\text { Do you prefer Indian dramas are to be } \\
\text { the best source of information on new } \\
\text { designs and fashion trends? }\end{array}$} & \multirow[t]{2}{*}{ Agree } & Count & 8 & 6 & 5 & 19 \\
\hline & & $\%$ of Total & $8.0 \%$ & $6.0 \%$ & $5.0 \%$ & $19.0 \%$ \\
\hline & \multirow[t]{2}{*}{ Strongly agree } & Count & 22 & 20 & 8 & 50 \\
\hline & & $\%$ of Total & $22.0 \%$ & $20.0 \%$ & $8.0 \%$ & $50.0 \%$ \\
\hline & \multirow[t]{2}{*}{ Disagree } & Count & 9 & 8 & 4 & 21 \\
\hline & & $\%$ of Total & $9.0 \%$ & $8.0 \%$ & $4.0 \%$ & $21.0 \%$ \\
\hline & Strongly disagree & Count & 6 & 4 & 0 & 10 \\
\hline & & $\%$ of Total & $6.0 \%$ & $4.0 \%$ & $0 \%$ & $10.0 \%$ \\
\hline \multirow[t]{2}{*}{ Total } & & Count & 45 & 38 & 17 & 100 \\
\hline & & $\%$ of Total & $45.0 \%$ & $38.0 \%$ & $17.0 \%$ & $100.0 \%$ \\
\hline
\end{tabular}

Table 2: Reveals to that half of the respondents determinedly consented that Indian dramatization. 
Shahbaz [7] likewise expresses that these dramatizations are exceptionally well known among a huge dominant part of digital audience members. Projection of swelled type of upper working class Indian culture through Star Plus isn't just estimated a disturbing sign in Pakistan yet it is faulted in India as well. Anjlee et al. [8] examined that the way of life portrayed in Star Plus cleanser musical shows, that isn't Indian, and is making outrage among Indians moreover. Essentially, another investigation expressed by Butt in 2005 analyzed the projection of Hindu religion in Star Plus cleanser musical dramas.

Today, media plays out a key part in progression of Hindi Language in Pakistan. Pakistani youngsters are more natural of Hindi culture and Hindi Language than their own way of life and dialect and it is a result of Indian media, kids use to combine Hindi words in Urdu dialect and utilize it in their day by day life like didi (sister), shantii(peace), Pati (companion) and jeej (brother in law) and so forth. Shahbaz [7] likewise contemplated on the "Effect of satellite TV stations on the general population living in Lahore" and the "Effect of Star Plus shows on youth in Pakistan" correspondingly, additionally featured because of Star Plus family dramatizations on social and social estimations of Pakistani youth of the working class. This examination incorporates that social-social musings of Pakistani youth is under the effect of far off social esteems. They have additionally affected dialect, form, nourishment, social conduct and day by day life of Pakistani society. The eastern and western societies are blended in these dramatizations, deduced in a "global culture" and advancing neutrality and modernization in Pakistani society [9-11].

The examination uncovers that India isn't genuine which Indian now a days appearing in their dramatizations. They simply concentrate on positive purposes of their way of life, society, their religion, patriotism and fealty with their nation. This thing particularly leaves an effect of the psyche of youthful age, for the most part on youngsters, on the grounds that in the event that they watch Indian shows they will likewise shape great outline of India in their brain. Presently kids are more well-known from Hindu society and Hindu convention than their own particular culture and custom in the event that they watch dramatizations in which India demonstrate fealty toward their own nation and religion than what sort of picture Pakistani kids are getting, government must expect over it. There ought to be different advances that ought to be taken to leave a positive effect on the general public. To start with, the administration should boycott Star additionally, Colors TV and other Indian cryptic TV channels. The guardians can recognize what their kids are viewing and the Government can identify what far off channels are showing by setting up a watch group. Pakistan channel should make those sort of dramatizations in which they should help our own particular religion commitment since some our TV channels likewise demonstrate Hindu culture in dramatizations, they should demonstrate our own training, culture, custom and convention [12].

The discoveries uncovered that it is the perspective of $94 \%$ members that media is supplanting the Pakistani culture from Pakistani society by demonstrating the Indian culture in TV shows and in different projects. Moreover, it was seen by the discoveries that $86 \%$ members concur that digital TV is performing key part in the progression of Indian culture in our Pakistani culture. Individuals can't overlook the truth that Pakistani media is likewise following the Indians since Pakistani TV dramatizations are built up like the happiness of Indian shows and along these lines it is insight of $90 \%$ members that Pakistani media is additionally advancing the Indian conventions, values and their traditions in the Pakistani society. It is seen that $62 \%$ has cell tune of Indian melodies which is the solid prop to that review how much the
Indian media is affecting our way of life while just $29 \%$ has Islamic tune on their mobile phone. A large portion of the Pakistani individuals are the devotee of Indian music as Flanagan considered that 71 million cell phones in Pakistan are having Indian tunes on their ringtones. It was investigated that $87 \%$ pointed individuals are fulfilled that our general public is following the Indian practices, for example, festivity of such conventions like Holi, basant, mehndi capacity, moving and different traditions of wedding. This condition indicates to a great degree high cautioning to Pakistani culture [13-15]

\section{Conclusion}

This study investigated the "Impact about Indian dramatizations with respect to dialect, furthermore dressing for females concentrating on female's students studying in Kinnaird College". Reception level of Indian society in Pakistan may be expanding step by step in view Indian networking is showing such substance which draw in the individuals from claiming Pakistan. These substances from claiming Indian networking are reinstating values. Pakistani society should contend with Indian media, Pakistani networking is likewise accompanying the Indian networking; they are showing such substance which promotes Indian society. In our society people give importance to other culture then their own because of viewing Indian dramas. Female prefers to watch fantasy program to escape them from real life. Watching of cable television is now included in daily routine activities. Even that cable television is watching only for entertainment purpose but some time the viewer is that much unconsciously affected to change their attitude, behavior and go beyond from the real life and personal values. We as a society must clear out these conventions and take on those customs that are characterized by Islam. We ought to further bolster our Pakistani social personality. We should not act according to Indian custom in light of these new social patterns that are against Islam instead following our own religion and our own customs which are our identity. In this way, Pakistani networking ought to assume its key part in promoting our culture not only at national level but also at the international level.

\section{References}

1. Joshi PC (1985) An Indian personality for television: Report of the working group on Software for Doordarshan, New Delhi: Government of India.

2. Rahim A (1994) Impact of cable TV on television and video viewing in Hyderabad: A survey. Media Asia: an Asian mass communication quarterly 21: $15-20$

3. Zia A (2003) Consumption of cable television, a research report published in: cable television, A vision of the future. (pp. 56-61). Pakistan Electronic Media Regulatory Authority Islamabad, Pakistan.

4. Batool U (2007) What are impacts of Indian dressing in Pakistan? Society and politics.

5. Ali A, Khalid A, Hassan A (2014) The Impact of Indian Dramas on Language and Dressing of Females 3 page 66 IOSR Journal Of Humanities And Social Science (IOSR-JHSS) 19: 66-71.

6. Qamar M, Asim M, Shawar D, Zafar MI (2012) "The Impacts Assessment of Indian Culture on Pakistani Society in Faisalabad". International Journal of Research in Social Sciences And Humanities 1: 53-62.

7. Shahbaz Z(2004) Impact of cable TV channels Star Plus soap operas on social and cultural norms and values of Pakistani youth. (P.123) Unpublished master"s thesis, Department of Mass Communication, Lahore College for Women University, Lahore.

8. Anjlee, Loona, Towhid (2006) Star Plus Indian drama. Retrieved April 3, 2007.

9. Arif I (2006) Media Imperialism and its effects on culture of Pakistan: A case study of youth of Multan Bahauddin Zikriya University Multan

10. Anwar BS (2005) "Hindi Serials". 
Citation: Wahid S (2018) The Changes in Language and Dressing of Females on Impact of Indian Dramas. J Mass Communicat Journalism 8: 380. doi: 10.4172/2165-7912.1000380

Page 5 of 5

11. Durham MG, Kellner DM (2006) "Media and Cultural Studies" Keyworks. Revised Edition. Dissertation Abstracts International, 50 (7), 2010-A.

12. Dash NK (2004) Social and cultural anthropology. New Delhi: Atlantic publisher.
13. Tamakuwala SJ (2011) Literature review.

14. Tylor EB (1920) Primitive culture. New York: J.P. Putnam's sons. p. 410.

15. Zia A (2007) Effects of cable television on the women in Pakistan: A comparative study of heavy and light viewers in Lahore (Doctorial dissertation). 